\title{
Synthesis of some New Schiff Bases and Hydrazones Containing Benzonaphthyridine/ Benzonaphthyridone Moiety
}

\author{
Rafid K. Jameel Attallah M. Sheat \\ Department of Chemistry/ College of Science/ University of Mosul
}

(Received 19/3/2013; Accepted 23/9/2013)

\begin{abstract}
The N-(4-methyl-2-pyridyl)anthranilic acid (I) was synthesized by Ullmann condensation. The compound (I) was cyclized by polyphosphoric acid (PPA) to give 4-methyl-10Hbenzo[b][1,8]naphthyridin-5-one (II). The compound (II) was treated with selenium dioxide $\left(\mathrm{SeO}_{2}\right)$ and thionyl chloride $\left(\mathrm{SOCl}_{2}\right)$ to give the 4-formyl-10H-benzo[b][1,8]naphthyridin-5-one (III) and 4methyl-5-chloro-benzo[b][1,8]naphthyridine (IV) respectively. The compound (III) was reacted with various substituted anilines and aliphatic amines to give the Schiff bases (Va-j). The compound (IV) was reacted with hydrazine hydrate to yield the 5-hydrazino derivative (VI), which was reacted with various aromatic aldehydes to yield the hydrazones (VIIa-j) and the $\mathrm{R}_{\mathrm{f}}$ values reported.The reaction progress was followed by thin layer chromatography (TLC). The synthesized compounds were confirmed by spectral data (I.R, ${ }^{1} \mathrm{H}-\mathrm{NMR},{ }^{13} \mathrm{C}-\mathrm{MNR}$ ). The possible fragmentation pattern of $\mathrm{GC} / \mathrm{MS}$ for the compounds (III), (Vc) and (VIIg) were reported.
\end{abstract}

\section{تحضير بهض قواعسشف وهيرالزونات جيلمحتوبة عل مجموعة البنزوفثارين/ البنزوفثاربدن}

\section{الملإص}

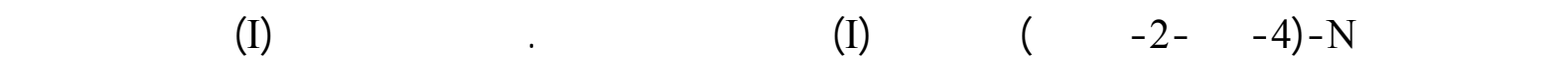

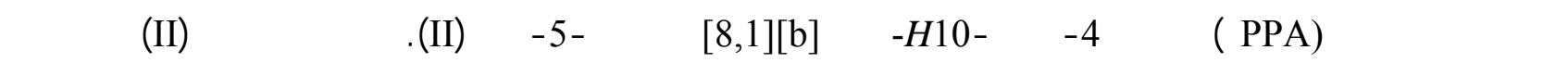

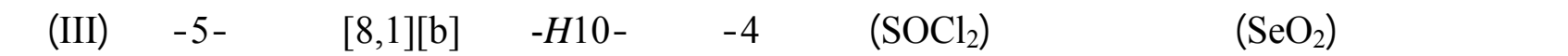
4 - مثيل -5 -كلورو بنزو[8,1][b ففثارين (IV) على التوالي.عند مفاعلة المركب (III) مع عدة أنيلينت معوضيدة وأمينات

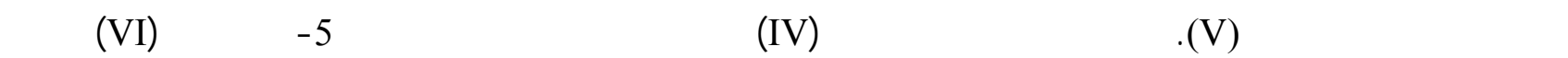

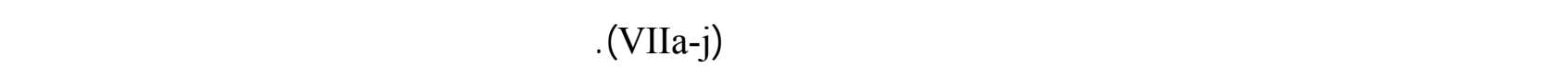
(TLC)

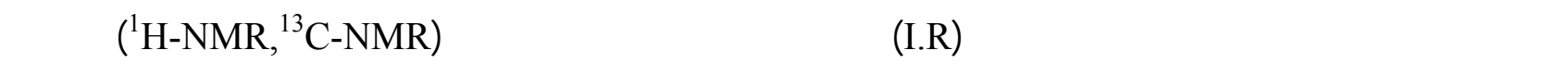
مخطط التجزؤ المحتطل لطف الكتلة (GC/MS) للمركبلت ( III, Vc, VIIg).

\section{INTRODUCTION}

Many Benzonaphthyridine derivatives have current interest due to their planner linear structure (Ivanove et al., 2005). Ullmann synthesis involves the condensation of $o$-halobenzoic acid with substituted 2-aminopyridine in presence of cupric oxide and anhydrous potassium carbonate to give N-pyridylanthranilic acids (Jameel and Al-Hadedi, 2010). Cyclization of N-pyridylanthranilic acid can be achived by concentrated $\mathrm{H}_{2} \mathrm{SO}_{4}$ (Acheson, 1973), polyphosphoric acid (PPA) (Meftah et al., 1994) and $\mathrm{POCl}_{3}$ (Al-Hadedi, 2008) to give different types of tricyclic hetero compounds. The literatures showed that the benzonaphthyridine/ benzonaphthyridone derivatives have versatile biological activities such as antitumor (Chen et al., 1994), trypanocidal (Mefetah et 
al., 1994), antimicrobial (Tabart et al., 2001), antibacterial (Tabart et al., 2003), anticancer (Deady et al., 2003), anticolinesterase (Marco et al., 2004), antimalarial (Gorlitzer et al., 2007), anti-HSV-1(Pincheiro et al., 2008), antifungal (Bhambi et al., 2009), anti-intestinal activity (Duan et al., 2011), and used as anti-inflammatory agent (Flockerzi et al., 2012). A new series of benzonaphthyridine/ benzonaphthyridone derivatives containing fused ring, such as imidazo (pyridino) group (Ming et al., 2011), pyrazolo group (Bernardino et al., 2012), were designed and synthesized.

In our previous work, a new benzonaphthyridine and benzonaphthyridone derivatives were synthesized, mainly sulpha drug-benzo[b][1,8]naphthyridine (Al-Hadedi, 2008), 10H-benzo[b][1,8]naphthyridin-5-one hydrazones (Al-Hadedi, 2009; Al- Obaydee, 2010) and 10-(alkyl, alkylhalide, benzoyl)benzo[b][1,8]naphthyridin-5-one (Al-Obaydee, 2010). The aim of the present study is preparation of new Schiff bases and hydrazones derivatives cotaining benzonaphthyridine/ benzonaphthyridone which were expected to be biologically active compounds.

\section{EXPERIMENTAL}

Melting points were determined on an electrothermal IA 9300 Digital-series (1998) apparatus, and they were uncorrected. Infrared spectra were recorded on a Bruker FT-IR spectrophotometer Tensor 27, Germany (College of Education, University of Mosul). ${ }^{1} \mathrm{H},{ }^{13} \mathrm{C}$-NMR spectra were recorded on a Bruker $300 \mathrm{MHz}$, in (Al-Al-Bayt University, Jordan) using TMS as an internal reference, and DMSO- $\mathrm{d}_{6}$ as a solvent, and coupling constant $\mathrm{J}(\mathrm{Hz})$ with the use of the following abbreviations: $s$, singlet; $d$, doublet; $t$, triplet; $m$, multiplet and br, broad. Mass spectra (MS) were obtained from perkin Elmer Clarus 500 Gas chromatography-Mass spectrometer in (I.I.T Roorkee. Chemistry Dept., India), and from a trace 2000 series GC-MS in $\mathrm{CH}_{2} \mathrm{Cl}_{2}$ University of Southampton, Chemistry Dept., UK).

Preparation of N-(4-methyl-2-pyridyl)anthranilic acid (I).

This compound was prepared by the procedure reported in the previous work (Jameel and AlHadedi, 2010).

\section{Preparation of 4-Methyl-10H-benzo[b][1,8]naphthyridin-5-one (II).}

This compound was prepared by the procedure reported in the previous work (Al-Hadedi, 2009; Al-Obaydee, 2010).

Preparation of 4-formyl -10H-benzo[b][1,8]naphthyridin-5-one (III). (Chen and Deady, 1993).

In a $100 \mathrm{ml}$ three-necked flask with sealed stirrer, a reflux condenser and a thermometer, 15 $\mathrm{ml}$ of dioxane was placed,then $(1.32 \mathrm{~g}, 0.0119 \mathrm{~mol})$ of selenium dioxide $\mathrm{SeO}_{2}$ and $(1 \mathrm{ml})$ water was added to the flask. The mixture was heated to $50-55^{\circ} \mathrm{C}$ until the solid was dissolved. The thermometer was removed and $(2.5 \mathrm{~g}, 0.0119 \mathrm{~mol})$ of compound (II) was added in one partion. The mixture was refluxed with stirring for $4 \mathrm{hrs}$. The progress of the reaction was monitored by TLC. The hot solution was decanted from the precipitated (black) selenium through fluted filter paper. The dioxane and water were removed by distillation to give a solid product. The product was recrystallized from ethanol to yield a brown powder, m.p $=170-172{ }^{\circ} \mathrm{C}, \mathrm{R}_{\mathrm{f}}=0.62$, yield $2.2 \mathrm{~g}$ $(83 \%)$.

Preparation of 4-[(1E)-(aryl or alkylimino)methyl]-10H-benzo[b][1,8]napthyri-dine-5-one, (Va-j). (kannappan et al., 2009).

General procedure.

In a $25 \mathrm{ml}$ dry methanol, $(0.1 \mathrm{~g}, 0.00044 \mathrm{~mol})$ of III was dissolved by stirring and mixed with $(0.00044 \mathrm{~mol})$ of appropriate amine. The solution was refluxed with stirring for at least $6 \mathrm{hrs}$. The progress of the reaction was monitored by TLC. The mixture was cooled and left overnight to complete the precipitation. The product was filtered off and dried in air. Table (1) summarizes the physical data for compounds Va-j. 
Table 1: Some physical data for compounds Va-j.

\begin{tabular}{|c|c|c|c|c|c|}
\hline $\begin{array}{c}\text { Compd. } \\
\text { No. }\end{array}$ & $\mathbf{R}$ & $\mathbf{m} \cdot \mathbf{p}^{\circ} \mathbf{C}$ & $\mathbf{R}_{\mathbf{f}} *$ & Color & Yield \% \\
\hline $\mathrm{Va}$ & 4- $\mathrm{CH}_{3} \mathrm{C}_{6} \mathrm{H}_{4^{-}}$ & $241-242$ & 0.27 & Yellow & 50 \\
\hline $\mathrm{Vb}$ & $3-\mathrm{CH}_{3} \mathrm{C}_{6} \mathrm{H}_{4}-$ & $232-236$ & 0.22 & Pale yellow & 42 \\
\hline $\mathrm{Vc}$ & $3,4-\mathrm{diCH}_{3} \mathrm{C}_{6} \mathrm{H}_{3-}$ & 234-230 & 0.21 & Yellow & 55 \\
\hline $\mathrm{Vd}$ & $2-\mathrm{NO}_{2} \mathrm{C}_{6} \mathrm{H}_{4-}$ & $>340$ & 0.15 & Red & 42 \\
\hline $\mathrm{Ve}$ & $4-\mathrm{NO}_{2} \mathrm{C}_{6} \mathrm{H}_{4}^{-}$ & $278-280$ & 0.23 & Red & 40 \\
\hline $\mathrm{Vf}$ & 2- $\mathrm{NH}_{2} \mathrm{C}_{6} \mathrm{H}_{4}-$ & $250-252$ & 0.11 & Pale black & 40 \\
\hline $\mathrm{Vg}$ & $\mathrm{CH}_{3} \mathrm{CH}_{2} \mathrm{CH}_{2-}$ & $171-173$ & 0.21 & Brown & 45 \\
\hline $\mathrm{Vh}$ & $\mathrm{CH}_{3} \mathrm{CH}_{2} \mathrm{CH}_{2} \mathrm{CH}_{2-}$ & $179-181$ & 0.2 & Brown & 47 \\
\hline $\mathrm{Vi}$ & $\mathrm{CH}_{3} \mathrm{CH}_{2} \mathrm{CH}_{2} \mathrm{CH}_{2} \mathrm{CH}_{2-}$ & $187-189$ & 0.2 & Brown & 47 \\
\hline $\mathrm{Vj}$ & $\mathrm{NH}_{2}$ & $199-201$ & 0.6 & Orange & 35 \\
\hline
\end{tabular}

- Elution solvent $=\mathrm{CHCl}_{3}: \mathrm{MeOH}(9.5: 0.5)$.

\section{Preparation of 5-chloro-4-methylbenzo[b][1,8]naphthyridine (IV). (Atwell et al., 1984).}

A mixture of $(2.5 \mathrm{~g}, 0.012 \mathrm{~mol})$ of compound II with excess $(30 \mathrm{ml})$ of $\mathrm{SOCl}_{2}$ containing (2 drops) DMF was refluxed for $3 \mathrm{hrs}$. The excess $\mathrm{SOCl}_{2}$ was distilled off under reduced pressure, then the deep scarlet thick residue was diluted with cold chloroform, $150 \mathrm{ml}$ (needs $2 \mathrm{hrs}$ ). The solution was slowly added with vigorous stirring to cold ammonia solution. The chloroform layer was separated and the aqueous alkaline solution was further extracted with $(30 \mathrm{ml} \times 2)$ of chloroform. The combined chloroform extracts were dried by magnesium sulfate for over night. The Chloroform filtrate was evaporated until dryness. The solid residue was recrystalyzed from ethanol to yield a brown powder, m.p $=116-118^{\circ} \mathrm{C} . \mathrm{R}_{\mathrm{f}}=0.95,\left(\mathrm{CHCl}_{3}: \mathrm{MeOH}, 9.5: 0.5\right)$, yield 85\%. (Lit. Al-Hadedi, 2009), $118-120^{\circ} \mathrm{C}, \mathrm{Rf}=0.66$.

Preparation of $\mathrm{N}-\{4-$-methylbenzo[b][1,8]naphthyridin-5-yl $\}$ hydrazine (VI). (Chandra et al., 2010; Al-Hadedi, 2009).

Compound IV $(3 \mathrm{~g})$ was added with stirring to the refluxing solution of hydrazine hydrate $(30 \mathrm{ml}, 80 \%)$ in $(150 \mathrm{ml})$ ethanol during $10 \mathrm{~min}$, and the refluxing continued for $40 \mathrm{~min}$. The completion of the reaction was monitored by TLC. The solvent was distilled under reduced pressure, then extracted by chloroform $(100 \mathrm{ml} \times 3)$, and dried by magnesium sulfate overnight. Filtration and evaporation of the solvent to dryness, recrystilazation from ethanol to yield a brown powder, m.p $=103-105{ }^{\circ} \mathrm{C}, \mathrm{Rf}=0.34\left(\mathrm{CHCl}_{3}: \mathrm{MeOH}\right.$, 9.5:0.5), yield 90\%. (Lit. Al-Hadedi, 2009), m. $p=103-105{ }^{\circ} \mathrm{C}, \mathrm{Rf}=0.31$, yield $73 \%$.

Preparation of substituted (1E)-benzyliden-N-\{4-methylbenzo-[b][1,8]naphthyridin-5yl\}hydrazine, (VIIa-j). (Kannappan, et al., 2009).

General procedure

A mixture of $(0.1 \mathrm{~g}, 0.00044 \mathrm{~mol})$ of VI in $25 \mathrm{ml}$ of methanol was mixed with $(0.00044 \mathrm{~mol})$ of appropriate aldehydes. The solution was refluxed with stirring for at least $6 \mathrm{hrs}$. The progress of the reaction was monitored by TLC. The mixture was cooled and left overnight to complete the fine precipitation. The product was filtered off and dried in air. Table (2) summarizes the physical data for compounds VIIa-j. 
Table 2: Some physical data for compound VIIa-j

\begin{tabular}{|c|c|c|c|c|c|}
\hline $\begin{array}{c}\text { Compd. } \\
\text { No. }\end{array}$ & $\mathbf{A r}$ & $\mathbf{m . p}{ }^{\circ} \mathbf{C}$ & $\mathbf{R}_{\mathbf{f}}$ & Color & Yield \% \\
\hline VIIa & $\mathrm{C}_{6} \mathrm{H}_{5}$ & $110-111$ & 0.89 & Yellow & 45 \\
\hline VIIb & $4-\mathrm{CH}_{3} \mathrm{C}_{6} \mathrm{H}_{4}$ & $158-160$ & 0.96 & Pale yellow & 42 \\
\hline VIIc & $2-\mathrm{HOC}_{6} \mathrm{H}_{4}$ & $218-220$ & 0.91 & Yellow crystal & 40 \\
\hline VIId & $4-\mathrm{BrC}_{6} \mathrm{H}_{4}$ & $228-229$ & 0.95 & Pale yellow & 50 \\
\hline VIIe & $4-\mathrm{NO}_{2} \mathrm{C}_{6} \mathrm{H}_{4}$ & $220-222$ & 0.42 & Yellow & 70 \\
\hline VIIf & $3-\mathrm{NO}_{2} \mathrm{C}_{6} \mathrm{H}_{4}$ & $128-129$ & 0.43 & Pale yellow & 55 \\
\hline VIIg & $4-\mathrm{ClC}_{6} \mathrm{H}_{4}$ & $210-211$ & 0.92 & Pale yellow & 38 \\
\hline VIIh & $4-\mathrm{MeOC}_{6} \mathrm{H}_{4}$ & $169-170$ & 0.89 & Yellow & 40 \\
\hline VIIi & $4-\mathrm{HO}_{3} 3-\mathrm{MeOC}_{6} \mathrm{H}_{3}$ & 290 dec. & 0.85 & Brown & 41 \\
\hline VIIj & $\mathrm{C}_{6} \mathrm{H}_{5}-\mathrm{CH}_{-} \mathrm{CH}_{-}$ & 150 sub. & 0.57 & Yellow & 48 \\
\hline
\end{tabular}

Elution solvent $=\mathrm{CHCl}_{3}: \mathrm{MeOH}(9.5: 0.5)$. dec. $=$ decomposition; sub. $=$ sublimation

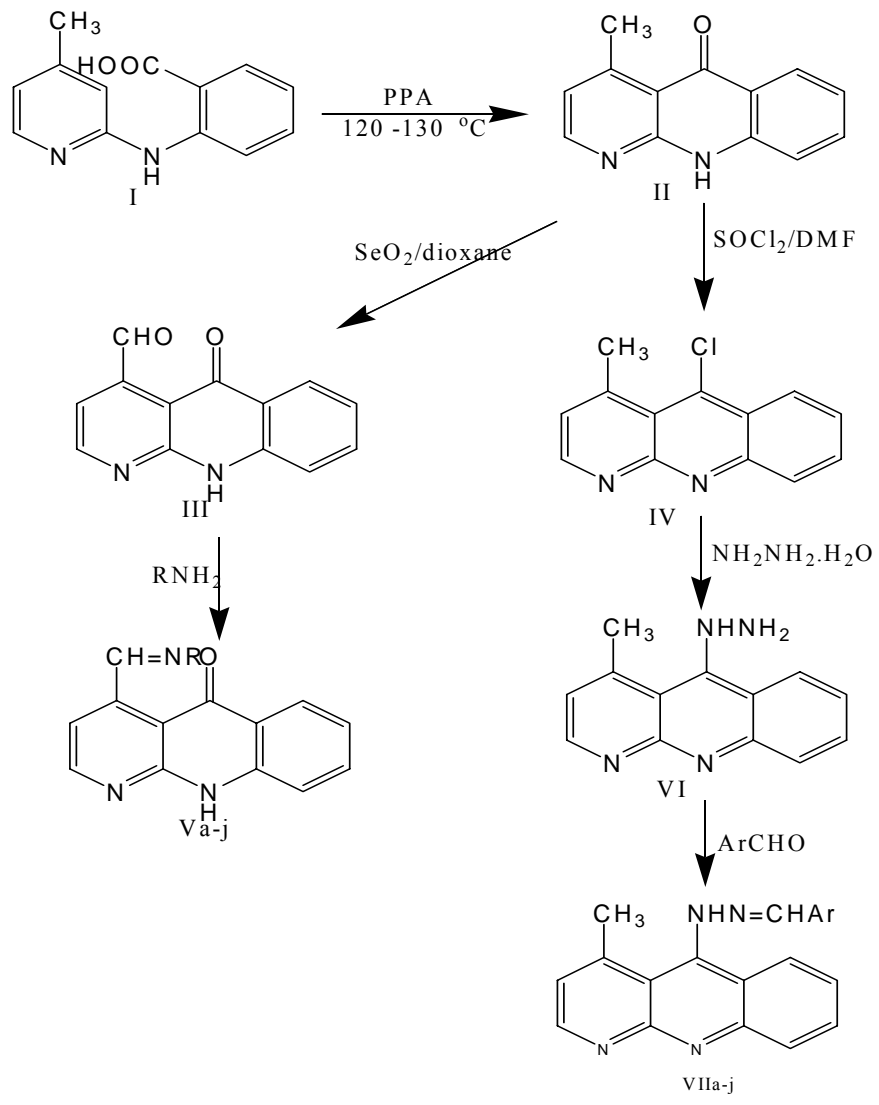

Scheme (1)

RESULTS AND DISCUSSION

The methyl group in compound (II) was easily oxidized to the corresponding formyl group to form the compound III as shown in Scheme 1. (Chen and Deady.,1993; Deady et al., 2003). The 
structure of compound III was confirmed via IR spectrum which showed characteristic absorption peaks in the region $\left(3479 \mathrm{~cm}^{-1}\right)$ due to the stretching of $(\mathrm{N}-\mathrm{H})$ bond, $\left(1705 \mathrm{~cm}^{-1}\right)$ due to the stretching of $(\mathrm{C}=\mathrm{O})$ bond of the aldehyde group, $\left(1687 \mathrm{~cm}^{-1}\right)$ due to stretching of $(\mathrm{C}=\mathrm{O})$ bond of the ketone group, and $\left(1637 \mathrm{~cm}^{-1}\right)$ due to stretching of $(\mathrm{C}=\mathrm{N})$ bond. The ${ }^{1} \mathrm{H}-\mathrm{NMR}$ and ${ }^{13} \mathrm{C}-\mathrm{NMR}$ spectral data of compound III confirmed the above results, and showed the following significant peaks: multiplet at 7.13-7.25 for $1 \mathrm{H}(\mathrm{H}-9)$, multiplet at 7.43-7.65 for $2 \mathrm{H}(\mathrm{H}-7, \mathrm{H}-8)$, multiple at 7.78-7.91 for $2 \mathrm{H}(\mathrm{NH}, \mathrm{H}-6)$, multiplet at $8.11-8.29$ for $1 \mathrm{H}(\mathrm{H}-3)$, multiplet at $8.64-8.77$ for $1 \mathrm{H}$ $(\mathrm{H}-2)$, singlet at 10.06 for $1 \mathrm{H}\left({ }^{\Perp} \mathrm{C}-\mathrm{H}\right)$. The ${ }^{13} \mathrm{C}-\mathrm{NMR}$ spectral data of the compound III showed the following significant peaks: $111.09\left(\mathrm{C}_{3}\right), 115.72\left(\mathrm{C}_{5 \mathrm{a}}\right), 111.64\left(\mathrm{C}_{9}\right), 116.7\left(\mathrm{C}_{4 \mathrm{a}}\right), 117.05\left(\mathrm{C}_{7}\right)$, 128.32( $\left.\mathrm{C}_{6}\right), 134.06\left(\mathrm{C}_{8}\right), 140.06\left(\mathrm{C}_{4}\right), 146.98\left(\mathrm{C}_{9 \mathrm{a}}\right), 148.28\left(\mathrm{C}_{2}\right), 158.95(\mathrm{C} 10 \mathrm{a}), 164.79\left(\mathrm{C}_{5}\right), 191.93$ $\stackrel{\mathrm{O}}{\stackrel{\mathrm{II}}{\mathrm{C}}-\mathrm{H})}$

$(-\stackrel{\|}{\mathrm{C}}-\mathrm{H})$. The mass spectral data Fig. (1) confirmed the above structure. The possible fragments $(\mathrm{m} / \mathrm{z})$ with their relative abundance (\%) was reported as shown in Scheme (2). Similar data were found in Lit (Tian et al., 2012)

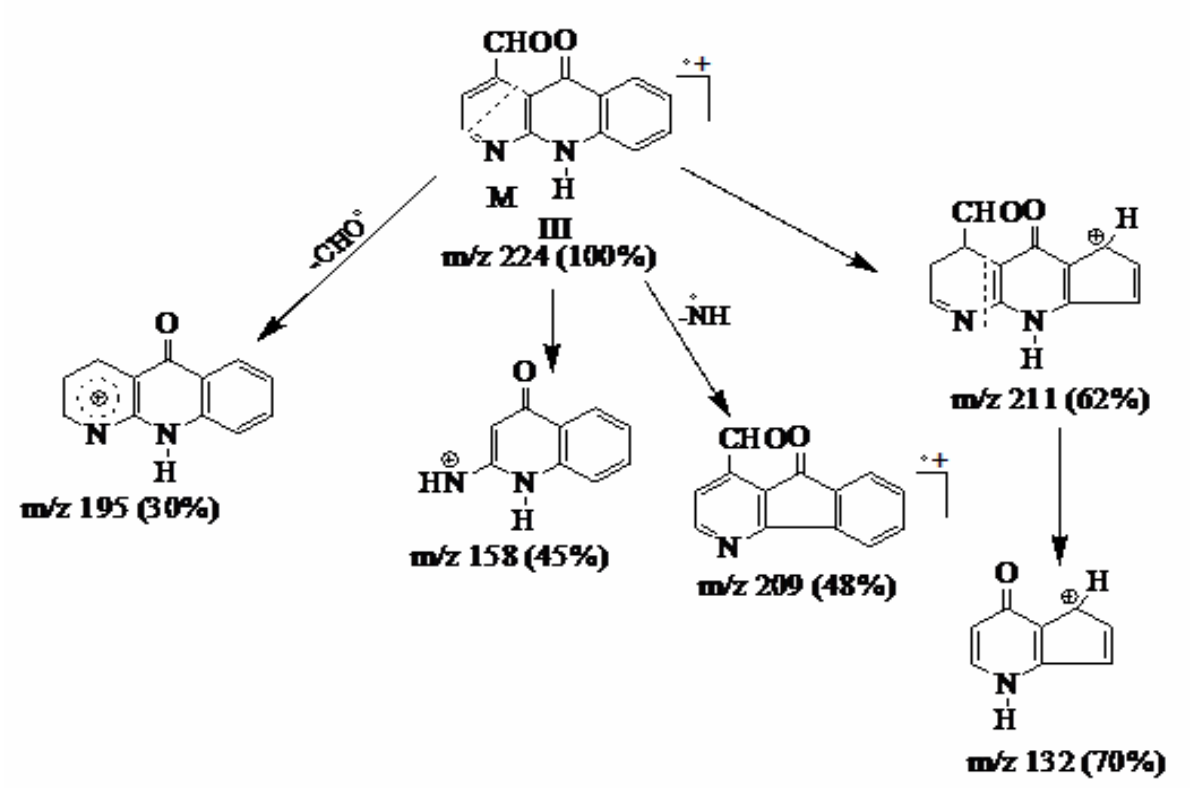

Scheme 2: Fragmentation pattern of compound (III)

The compounds Va-j( Deyanov and Konshin., 2004., Yi et al., 2008), have been prepared through the condensation of compound III with various substituted anilines or alkylamines. The structure of the prepared compounds Va-j, was elucidated by means of physical data Table (1) (m.p, $\mathrm{R}_{\mathrm{f}}$ ) and spectral data (Table 3). The IR spectra for compounds Va-j showed a characteristic absorption bands at $\left(3473-3255 \mathrm{~cm}^{-1}\right)$ due to stretching of $(\mathrm{N}-\mathrm{H})$ bond, $\left(1695-1682 \mathrm{~cm}^{-1}\right)$ due to stretching of $(\mathrm{C}=\mathrm{O})$ bond, $\left(1645-1649 \mathrm{~cm}^{-1}\right)$ stretching of $(\mathrm{C}=\mathrm{N})$ bond. The ${ }^{1} \mathrm{H}-\mathrm{NMR}$ and ${ }^{13} \mathrm{C}-\mathrm{NMR}$ spectral data (DMSO- $\mathrm{d}_{6}, \delta$ in ppm) confirmed the above results (Figs. 2, 3). The compound (Vc) was selected as a representative for this series, and showed the following significant ${ }^{1} \mathrm{H}-\mathrm{NMR}$ chemical shifts Fig. (4):

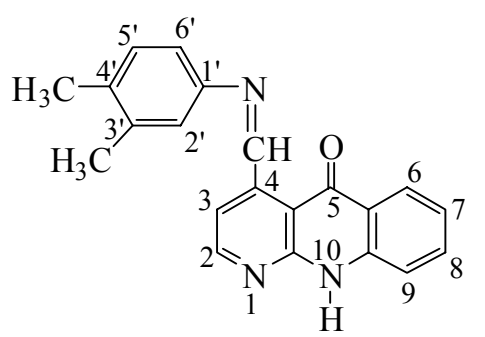


Two singlet at 2.32 and 2.34 , each for $3 \mathrm{H}$ for the two $\left(\mathrm{CH}_{3}\right)$ protons, six peaks for the nine aromatic protons: multiplet at 7.12-7.28 for $3 \mathrm{H}\left(\mathrm{H}^{\prime} 2^{\prime}, \mathrm{H}^{-} 5^{\prime}, \mathrm{H}-6^{\prime}\right)$, triplet at 7.54 for $1 \mathrm{H}(\mathrm{H}-8)$, doublet at 7.64 for $1 \mathrm{H}(\mathrm{J}=7 \mathrm{~Hz})(\mathrm{H}-3)$, singlet at 7.70 for $1 \mathrm{H}(\mathrm{CH}=\mathrm{N})$, multiplet at $7.85-7.89$ for $2 \mathrm{H}$ (NH, H-7), multiplet at $8.48-8.53$ for $2 \mathrm{H}(\mathrm{H}-6, \mathrm{H}-9)$, doublet at 8.90 for $1 \mathrm{H}(\mathrm{J}=7)(\mathrm{H}-2)$. The mass spectrum for compound Vc Fig. (5) showed the possible following fragmentation pattern $(\mathrm{m} / \mathrm{z})$ with the relative abundance of the fragments (\%) as shown in Scheme (3).

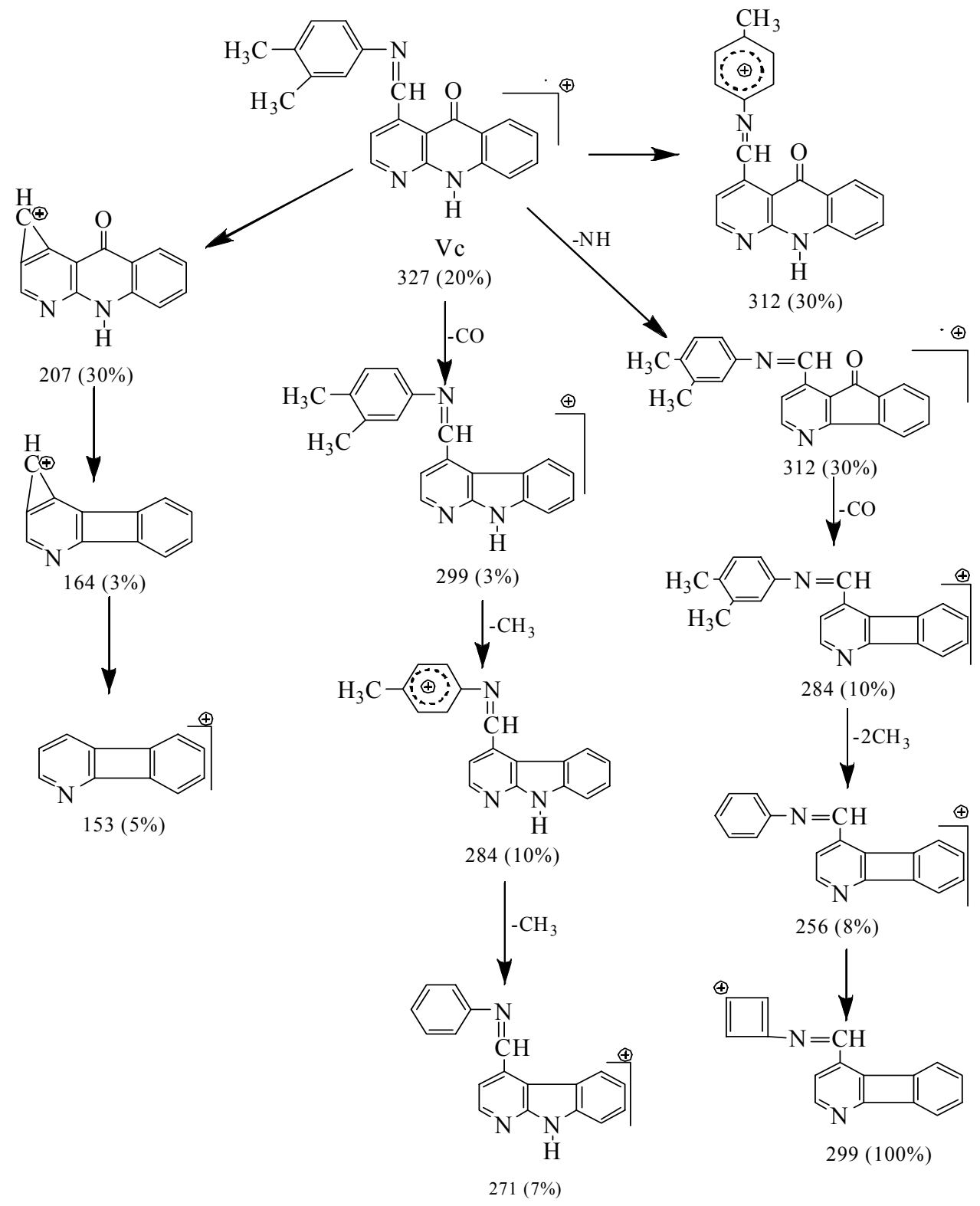

Scheme 3: Fragmentation pattern of compound (Vc) 
Table 3: Spectral data for compounds Va-j

\begin{tabular}{|c|c|c|c|}
\hline $\begin{array}{l}\text { Compd. } \\
\text { No. }\end{array}$ & \multicolumn{2}{|c|}{$\begin{array}{l}\text { IR (KBr) } \\
v\left(\mathbf{c m}^{-1}\right)\end{array}$} & ${ }^{1} \mathrm{H}-\mathrm{NMR} \&{ }^{13} \mathrm{C}-\mathrm{NMR}\left(\mathrm{DMSO}-\mathrm{d}_{6}\right) \delta \mathrm{ppm}$ \\
\hline \multirow{4}{*}{$\mathrm{Va}$} & $\mathrm{C}=\mathrm{C}$ & 1604 & \multirow{4}{*}{$\begin{array}{l}2.40\left(\mathrm{~s}, 3 \mathrm{H}, \mathrm{CH}_{3}\right), 7.25(\mathrm{~m}, 4 \mathrm{H}, \mathrm{ArH}), 7.53(\mathrm{t}, 1 \mathrm{H}, \mathrm{J}=7 \mathrm{~Hz}), 7.62(\mathrm{~d}, \\
1 \mathrm{H}, \mathrm{J}=7.5 \mathrm{~Hz}), 7.7(\mathrm{~s}, 1 \mathrm{H}), 7.82-7.88(\mathrm{~m}, 2 \mathrm{H}), 8.47-8.52(\mathrm{~m}, 2 \mathrm{H}), \\
8.88(\mathrm{~d}, 1 \mathrm{H}, 7.5 \mathrm{~Hz}) .\end{array}$} \\
\hline & $\mathrm{C}=\mathrm{N}$ & 1647 & \\
\hline & $\mathrm{C}=\mathrm{O}$ & 1685 & \\
\hline & $\mathrm{NH}$ & 3422 & \\
\hline \multirow{4}{*}{$\mathrm{Vb}$} & $\mathrm{C}=\mathrm{C}$ & 1605 & \multirow{4}{*}{$\begin{array}{l}2.37\left(\mathrm{~s}, 3 \mathrm{H}, \mathrm{CH}_{3}\right), 7.18-7.20(\mathrm{~m}, 3 \mathrm{H}), 7.36(\mathrm{~m}, 1 \mathrm{H}), 7.56(\mathrm{~m}, 2 \mathrm{H}), \\
7.83-7.95(\mathrm{~m}, 3 \mathrm{H}), 8.34(\mathrm{~m}, 1 \mathrm{H}), 8.81(\mathrm{~s}, 2 \mathrm{H}) .\end{array}$} \\
\hline & $\mathrm{C}=\mathrm{N}$ & 1649 & \\
\hline & $\mathrm{C}=\mathrm{O}$ & 1682 & \\
\hline & $\mathrm{NH}$ & 3417 & \\
\hline \multirow{4}{*}{$\mathrm{Vc}$} & $\mathrm{C}=\mathrm{C}$ & 1608 & \multirow{4}{*}{$\begin{array}{l}2.32\left(\mathrm{~s}, 3 \mathrm{H}, \mathrm{CH}_{3}\right), 2.34\left(\mathrm{~s} .3 \mathrm{H}, \mathrm{CH}_{3}\right), 7.12-7.28(\mathrm{~m}, 3 \mathrm{H}), 7.54(\mathrm{t}, \\
1 \mathrm{H}), 7.64(\mathrm{~d}, 1 \mathrm{H}, \mathrm{J}=7 \mathrm{H}), 7.70(\mathrm{~s}, 1 \mathrm{H}), 7.85-7.89(\mathrm{~m}, 2 \mathrm{H}) 8.48-8.53 \\
(\mathrm{~m}, 2 \mathrm{H}), 8.90(\mathrm{~d}, 1 \mathrm{H}, \mathrm{J}=7 \mathrm{~Hz}) .\end{array}$} \\
\hline & $\mathrm{C}=\mathrm{N}$ & 1647 & \\
\hline & $\mathrm{C}=\mathrm{O}$ & 1691 & \\
\hline & $\mathrm{NH}$ & 3473 & \\
\hline \multirow{4}{*}{$\mathrm{Vd}$} & $\mathrm{C}=\mathrm{C}$ & 1606 & \multirow{4}{*}{ 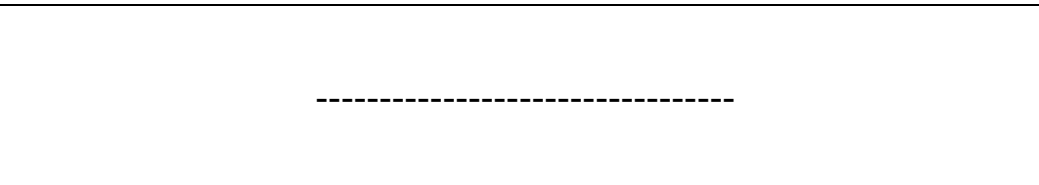 } \\
\hline & $\mathrm{C}=\mathrm{N}$ & 1647 & \\
\hline & $\mathrm{C}=\mathrm{O}$ & 1695 & \\
\hline & $\mathrm{NH}$ & 3419 & \\
\hline \multirow{4}{*}{$\mathrm{Ve}$} & $\mathrm{C}=\mathrm{C}$ & 1603 & \multirow{4}{*}{$\begin{array}{l}\text { 7.24-8.28 }(\mathrm{m}, 8 \mathrm{H}), 8.75-10.19(\mathrm{~m}, 4 \mathrm{H}) . \\
111.22,112.80,116.47,116.88,126.19,126.48,126.85,126.95, \\
127.23,127.56,127.91,128.67,134.23,135.70,136.82,147.38, \\
148.44,158.52,165.49\end{array}$} \\
\hline & $\mathrm{C}=\mathrm{N}$ & 1647 & \\
\hline & $\mathrm{C}=\mathrm{O}$ & 1685 & \\
\hline & NH & 3443 & \\
\hline \multirow{4}{*}{ Vf } & $\mathrm{C}=\mathrm{C}$ & 1600 & \multirow{4}{*}{$\begin{array}{l}\begin{array}{l}4.36 \quad\left(\mathrm{br}, 2 \mathrm{H}, \mathrm{NH}_{2}\right), \\
(\mathrm{m}, 3 \mathrm{H}), 8.49(\mathrm{~m}, 1 \mathrm{H}) .\end{array} \\
102.06,112.52,114.93,115.89,116.46,117.74,123.54,124.95, \\
126.18,127.02,127.17,127.44,127.69,128.23,135.37,144.52, \\
146.90,147.86,158.70,164.70\end{array}$} \\
\hline & $\mathrm{C}=\mathrm{N}$ & 1645 & \\
\hline & $\mathrm{C}=\mathrm{O}$ & 1684 & \\
\hline & $\begin{array}{c}\mathrm{NH} \\
\mathrm{NH}_{2}\end{array}$ & $\begin{array}{l}3422- \\
3260\end{array}$ & \\
\hline \multirow{4}{*}{$\mathrm{Vg}$} & $\mathrm{C}=\mathrm{C}$ & 1605 & \\
\hline & $\mathrm{C}=\mathrm{N}$ & 1645 & \\
\hline & $\mathrm{C}=\mathrm{O}$ & 1685 & \\
\hline & $\mathrm{NH}$ & 3422 & \\
\hline \multirow{4}{*}{ Vh } & $\mathrm{C}=\mathrm{C}$ & 1606 & \\
\hline & $\mathrm{C}=\mathrm{N}$ & 1646 & \\
\hline & $\mathrm{C}=\mathrm{O}$ & 1684 & \\
\hline & $\mathrm{NH}$ & 3418 & \\
\hline \multirow{4}{*}{$\mathrm{Vi}$} & $\mathrm{C}=\mathrm{C}$ & 1604 & \multirow{4}{*}{$\begin{array}{l}0.85(\mathrm{~s}, 3 \mathrm{H}), 1.27(\mathrm{~s}, 4 \mathrm{H}), 1.54(\mathrm{~s}, 2 \mathrm{H}), 2.38-2.86(\mathrm{~m}, 2 \mathrm{H}), 7.37- \\
7.49(\mathrm{br}, 2 \mathrm{H}), 7.74-7.88(\mathrm{~m}, 3 \mathrm{H}), 8.09-8.29(\mathrm{~m}, 2 \mathrm{H}), 8.45-8.73(\mathrm{~m}, \\
1 \mathrm{H}) . \\
14.41,22.11,27.25,29.43,30.42,114.43,116.48,125.04,125.30, \\
125.93,127.16,127.25,128.24,135.32,135.61,148.63,158.63, \\
164.87\end{array}$} \\
\hline & $\mathrm{C}=\mathrm{N}$ & 1647 & \\
\hline & $\mathrm{C}=\mathrm{O}$ & 1684 & \\
\hline & NH & 3430 & \\
\hline \multirow{4}{*}{$\mathrm{Vj}$} & $\mathrm{C}=\mathrm{C}$ & 1607 & \multirow{4}{*}{$\begin{array}{l}2.9\left(\mathrm{~s}, 2 \mathrm{H}, \mathrm{NH}_{2}\right), 7.04(\mathrm{~d}, 1 \mathrm{H}, \mathrm{J}=4.5 \mathrm{~Hz}), 7.24(\mathrm{t}, 2 \mathrm{H}, \mathrm{J}=7 \mathrm{~Hz}), 7.58- \\
7.73(\mathrm{~m}, 3 \mathrm{H}), 8.05(\mathrm{~d}, 1 \mathrm{H}, \mathrm{J}=7 \mathrm{~Hz}) 8.39(\mathrm{~d}, 1 \mathrm{H}, \mathrm{J}=4.5 \mathrm{~Hz}) \\
114.42,117.64,120.88,121.96,122.32,126.50,134.12,140.52, \\
146.83,152.17,152.61,153.50,179.30\end{array}$} \\
\hline & $\mathrm{C}=\mathrm{N}$ & 1645 & \\
\hline & $\mathrm{C}=\mathrm{O}$ & 1683 & \\
\hline & $\begin{array}{l}\mathrm{NH}, \\
\mathrm{NH}_{2}\end{array}$ & $\begin{array}{l}3417- \\
3255\end{array}$ & \\
\hline
\end{tabular}


Compound IV has been prepared through the chlorination of compound II with excess $\mathrm{SOCl}_{2}$ (Al-Hadedi, 2008; Al-Hadedi, 2009) as illustrated in Scheme (1). The structure of the synthesized compound IV was confirmed by means of physical data (m.p, $\mathrm{R}_{\mathrm{f}}$ ) and spectral data. The IR spectrum showed characteristic absorbtion peaks in the region $\left(1649 \mathrm{~cm}^{-1}\right)$ for stretching of $(\mathrm{C}=\mathrm{N})$ bond, $\left(1606 \mathrm{~cm}^{-1}\right)$ for stretching of $(\mathrm{C}=\mathrm{C})$ bond and there is absence of stretching band of $(\mathrm{C}=\mathrm{O})$ bond at $\left(1695 \mathrm{~cm}^{-1}\right)$.

Compound VI has been prepared through the reaction of compound IV with hydrazine hydrate (Chandra et al., 2010; Al-Hadedi, 2009) as shown in Scheme (1). The structure of the synthesized compound VI was confirmed by means of physical data (m.p, $\mathrm{R}_{\mathrm{f}}$ ) and spectral data. The IR spectrum showed a characteristic broad absorption peaks in the region $\left(3422-3314 \mathrm{~cm}^{-1}\right)$ which is due to the bond stretching of $\left(\mathrm{NH}, \mathrm{NH}_{2}\right)$ bonds, $1649 \mathrm{~cm}^{-1}$ for stretching of $(\mathrm{C}=\mathrm{N})$ bond, and $\left(1590 \mathrm{~cm}^{-1}\right)$ for stretching of $(\mathrm{C}=\mathrm{C})$ bond. The ${ }^{1} \mathrm{H}-\mathrm{NMR}$ and ${ }^{13} \mathrm{C}-\mathrm{NMR}$ spectral data for compound VI (Fig. 6) confirmed the above results and showed significant bands: singlet at 2.38 for $3 \mathrm{H}\left(\mathrm{CH}_{3}\right)$, singlet at 2.75 for $2 \mathrm{H}\left(\mathrm{NH}_{2}\right)$, broad band at 3.93-3.94 for $1 \mathrm{H}(\mathrm{NH})$. The chemical shifts of the aromatic protons are shown as following: doublet at 6.92 for $1 \mathrm{H}(\mathrm{J}=7.2 \mathrm{~Hz})(\mathrm{H}-3)$, doublet at 7.68 for $1 \mathrm{H}(\mathrm{J}=8 \mathrm{~Hz})(\mathrm{H}-8)$, multiplet at $7.84-7.89$ for $2 \mathrm{H}(\mathrm{H}-6, \mathrm{H}-7)$, doublet at 8.26 for $1 \mathrm{H}(\mathrm{J}=8 \mathrm{~Hz})(\mathrm{H}-$ 9), doublet at 8.69 for $1 \mathrm{H}(\mathrm{J}=7.2 \mathrm{~Hz})(\mathrm{H}-2)$. The ${ }^{13} \mathrm{C}-\mathrm{NMR}$ for compound VI in (DMSO- $\left.\mathrm{d}_{6}\right) \delta$ in ppm, showed the following chemical shifts: $20.78\left(\mathrm{CH}_{3}\right), 115.38\left(\mathrm{C}_{4 \mathrm{a}}\right), 115.99\left(\mathrm{C}_{5 \mathrm{a}}\right), 123.04\left(\mathrm{C}_{6}\right)$, $124.48\left(\mathrm{C}_{3}\right), 125.68\left(\mathrm{C}_{7}\right), 126.52\left(\mathrm{C}_{9}\right), 126.66\left(\mathrm{C}_{8}\right), 134.43\left(\mathrm{C}_{4}\right), 146.43\left(\mathrm{C}_{9 \mathrm{a}}\right), 147.37\left(\mathrm{C}_{5}\right), 148.56$ $\left(\mathrm{C}_{2}\right), 160.61\left(\mathrm{C}_{10 \mathrm{a}}\right)$.

The compounds VIIa-j have been prepared through the condensation of compound VI with various aromatic aldehydes (Chilin et al., 2002; Manoj and prasad ., 2011) as illustrated in Scheme (1). The structure of the prepared compounds was elucidated by means of physical data (Table 2) (m.p, $\mathrm{R}_{\mathrm{f}}$ ) and spectral data (Table 4). The IR spectra of compounds VIIa-j showed a characteristic absorption bands at (3340-3300 $\left.\mathrm{cm}^{-1}\right)$ for stretching of $(\mathrm{N}-\mathrm{H})$ band, $\left(1625-1635 \mathrm{~cm}^{-1}\right)$ for stretching of $(\mathrm{C}=\mathrm{N})$ bond. The ${ }^{1} \mathrm{H}-\mathrm{NMR}$ spectrum for compound VIIb confirmed the structure of these compounds. The mass spectrum for compound VIIg showed the possible following fragmentation $(\mathrm{m} / \mathrm{z})$ with relative abundance $(\%)$ as shown in Scheme (4). 


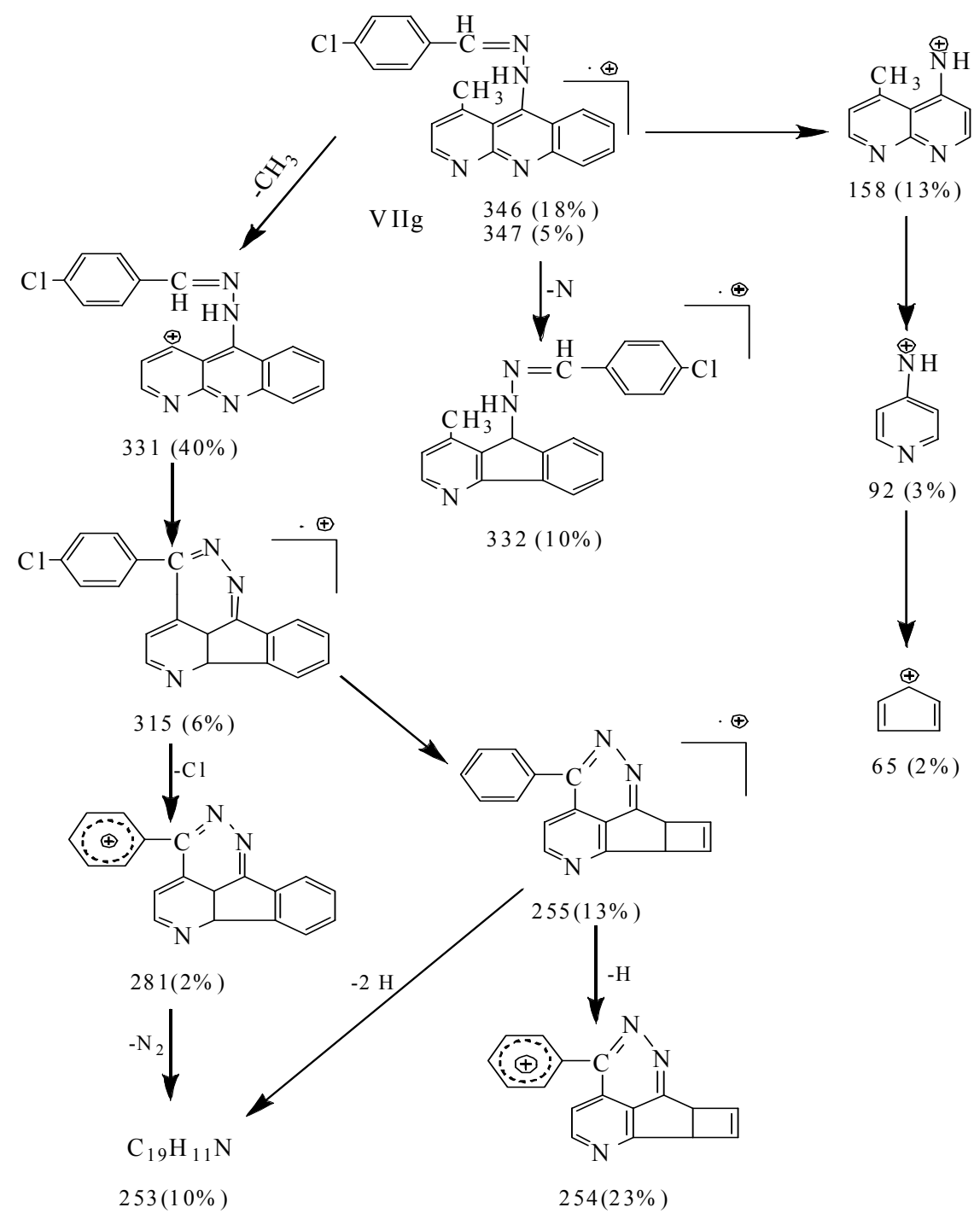

Scheme 4: Fragmentation pattern of compound (VIIg) 
Table 4: Spectral data for compounds VIIa-j

\begin{tabular}{|c|c|c|c|}
\hline $\begin{array}{c}\text { Compd. } \\
\text { No. }\end{array}$ & \multicolumn{2}{|c|}{ IR (KBr), v(cm $\left.{ }^{-1}\right)$} & ${ }^{1} \mathrm{H}-\mathrm{NMR}\left(\mathrm{DMSO}-\mathrm{d}_{6}\right) \delta \mathrm{ppm}$ \\
\hline \multirow{3}{*}{ VIIa } & $\mathrm{C}=\mathrm{C}$ & 1600 & \multirow{3}{*}{------- } \\
\hline & $\mathrm{C}=\mathrm{N}$ & 1624 & \\
\hline & $\mathrm{NH}$ & $4430-3310$ & \\
\hline \multirow{3}{*}{ VIIb } & $\mathrm{C}=\mathrm{C}$ & 1602 & \multirow{3}{*}{$\begin{array}{l}2.36\left(\mathrm{~s}, 3 \mathrm{H}, \mathrm{CH}_{3}\right), 2.39\left(\mathrm{~s}, 3 \mathrm{H}, \mathrm{CH}_{3}\right), 7.32(\mathrm{~m}, 5 \mathrm{H}), \\
7.77(\mathrm{~m}, 3 \mathrm{H}), 8.66(\mathrm{~m}, 2 \mathrm{H}) .\end{array}$} \\
\hline & $\mathrm{C}=\mathrm{N}$ & 1625 & \\
\hline & $\mathrm{NH}$ & $3440-3300$ & \\
\hline \multirow{3}{*}{ VIIc } & $\mathrm{C}=\mathrm{C}$ & 1601 & \multirow{3}{*}{$\begin{array}{l}2.54\left(\mathrm{~s}, 3 \mathrm{H}, \mathrm{CH}_{3}\right), 6.97-7.01(\mathrm{~m}, 4 \mathrm{H}), 7.40-7.42(\mathrm{~m}, \\
2 \mathrm{H}), 7.70-7.72(\mathrm{~m}, 2 \mathrm{H}), 9.00-9.05(\mathrm{~m}, 3 \mathrm{H}), 11.1(\mathrm{~s}, \\
1 \mathrm{H}) .\end{array}$} \\
\hline & $\mathrm{C}=\mathrm{N}$ & 1625 & \\
\hline & $\mathrm{NH}$ & $3566-3421$ & \\
\hline \multirow{3}{*}{ VIId } & $\mathrm{C}=\mathrm{C}$ & 1605 & \multirow{3}{*}{------- } \\
\hline & $\mathrm{C}=\mathrm{N}$ & 1625 & \\
\hline & $\mathrm{NH}$ & $3430-3310$ & \\
\hline \multirow{3}{*}{ VIIe } & $\mathrm{C}=\mathrm{C}$ & 1595 & \multirow{3}{*}{------- } \\
\hline & $\mathrm{C}=\mathrm{N}$ & 1635 & \\
\hline & $\mathrm{NH}$ & $3435-3325$ & \\
\hline \multirow{3}{*}{ VIIf } & $\mathrm{C}=\mathrm{C}$ & 1597 & \multirow{3}{*}{------- } \\
\hline & $\mathrm{C}=\mathrm{N}$ & 1635 & \\
\hline & $\mathrm{NH}$ & $3340-3360$ & \\
\hline \multirow{3}{*}{ VIIg } & $\mathrm{C}=\mathrm{C}$ & 1602 & \multirow{3}{*}{------- } \\
\hline & $\mathrm{C}=\mathrm{N}$ & 1630 & \\
\hline & $\mathrm{NH}$ & $3430-3340$ & \\
\hline \multirow{3}{*}{ VIIh } & $\mathrm{C}=\mathrm{C}$ & 1598 & \multirow{3}{*}{$\begin{array}{l}2.54\left(\mathrm{~s}, 3 \mathrm{H}, \mathrm{CH}_{3}\right), 3.82\left(\mathrm{~s}, 3 \mathrm{H}, \mathrm{OCH}_{3}\right), 7.05(\mathrm{~m}, \\
6 \mathrm{H}), 7.08(\mathrm{~m}, 4 \mathrm{H}), 8.63(\mathrm{~m}, 2 \mathrm{H}) .\end{array}$} \\
\hline & $\mathrm{C}=\mathrm{N}$ & 1628 & \\
\hline & $\mathrm{NH}$ & $3435-3340$ & \\
\hline \multirow{3}{*}{ VIIi } & $\mathrm{C}=\mathrm{C}$ & 1600 & \multirow{3}{*}{------- } \\
\hline & $\mathrm{C}=\mathrm{N}$ & 1625 & \\
\hline & $\mathrm{NH}$ & $3360-3410$ & \\
\hline \multirow{3}{*}{ VIIj } & $\mathrm{C}=\mathrm{C}$ & 1602 & \multirow{3}{*}{$2.54\left(\mathrm{~s}, 3 \mathrm{H}, \mathrm{CH}_{3}\right), 6.93-8.40(\mathrm{~m}, 15 \mathrm{H})$} \\
\hline & $\mathrm{C}=\mathrm{N}$ & 1630 & \\
\hline & $\mathrm{NH}$ & $3435-3340$ & \\
\hline
\end{tabular}


TIC: ID [AMM/AT5] Ref [aam1n10:30] Method [FAST CI-MS non-polar]

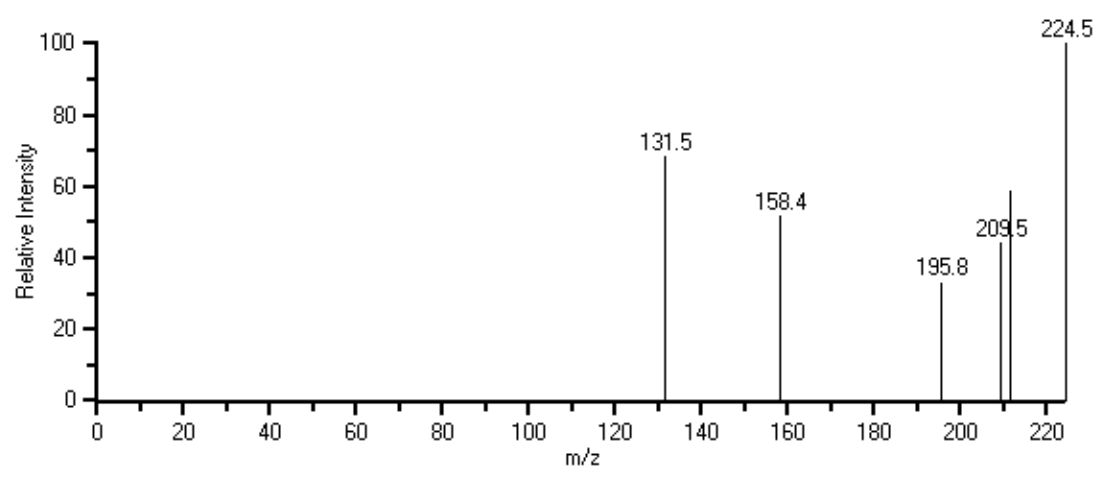

Fig. 1: Mass spectrum for compound (III)

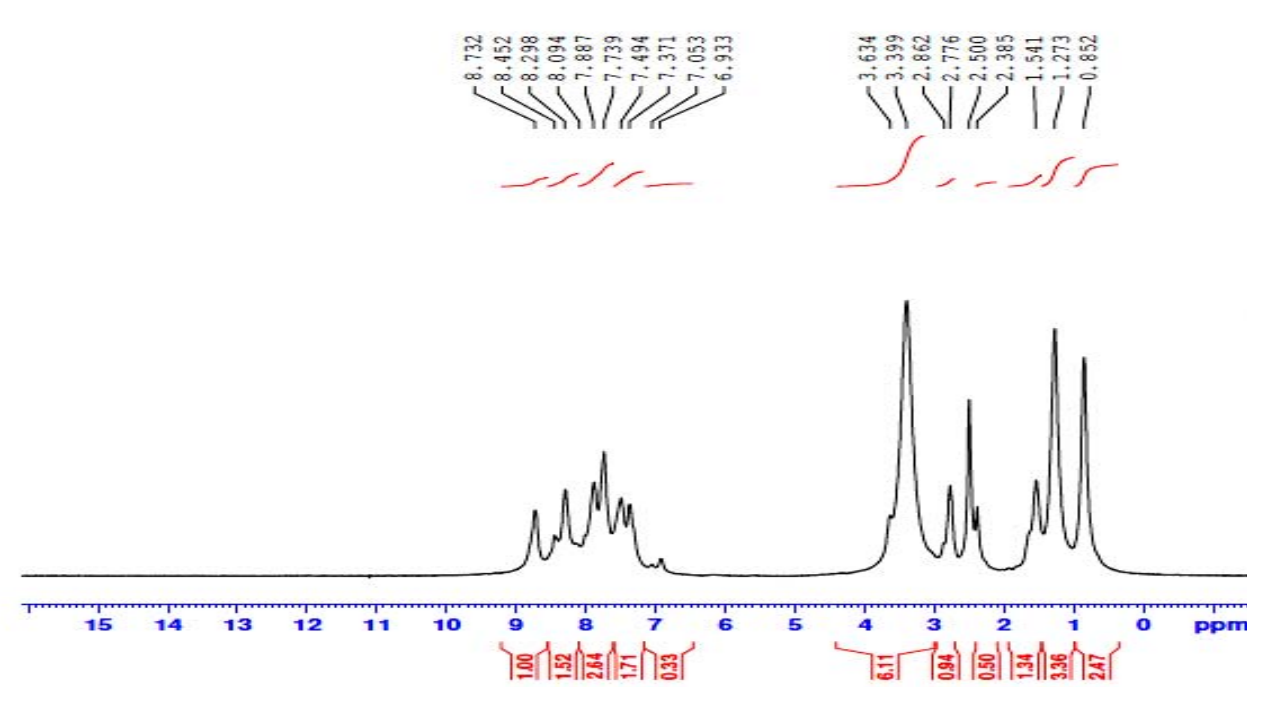

Fig. 2: ${ }^{1} \mathrm{H}-\mathrm{NMR}$ spectrum for compound (Vi)

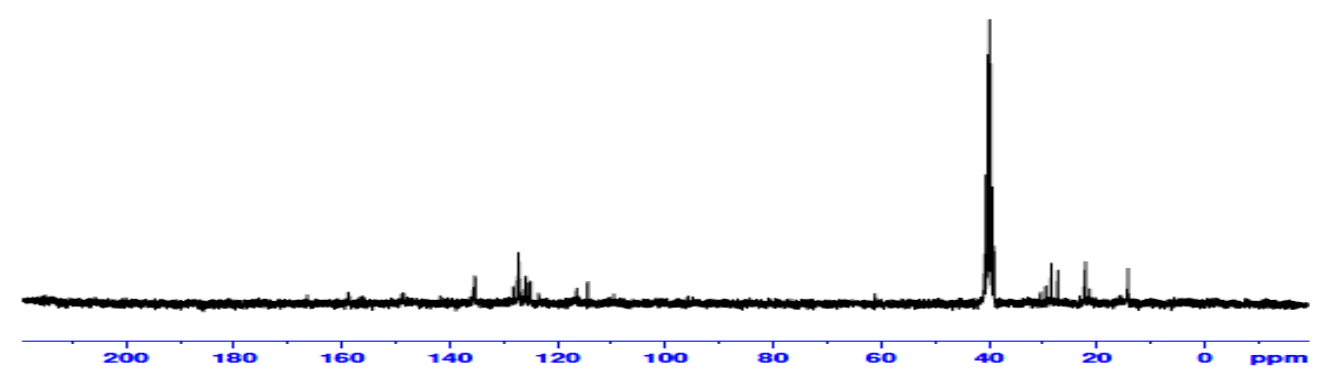

Fig. 3: ${ }^{13} \mathrm{C}-\mathrm{NMR}$ spectrum for compound (Vi) 


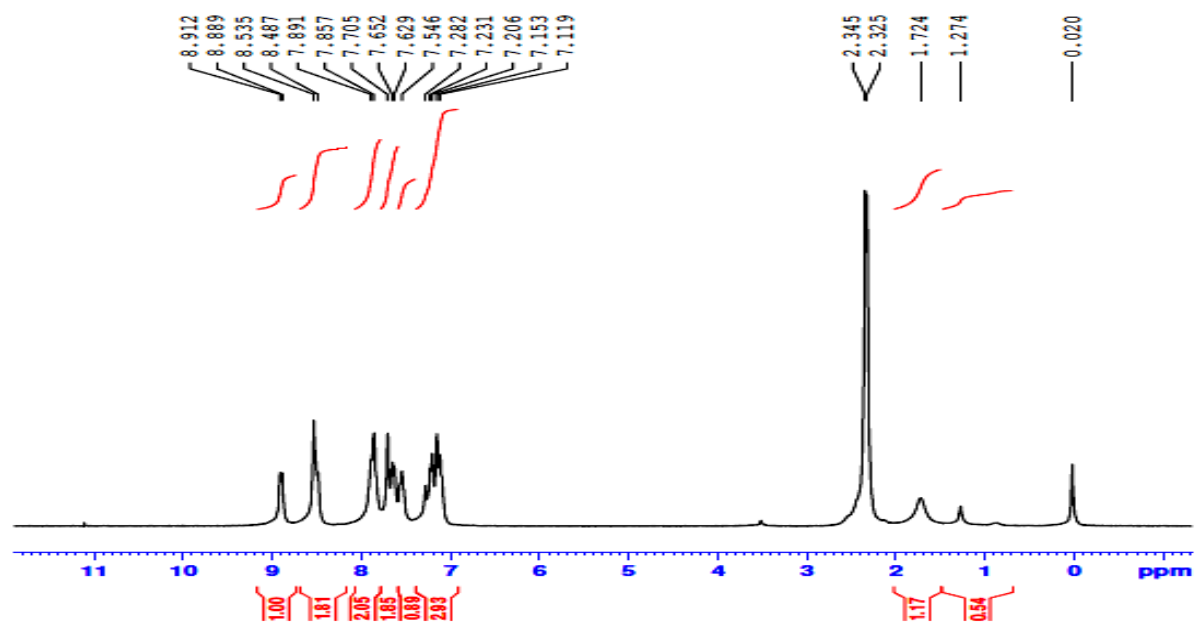

Fig. 4: 1H-NMR spectrum for compound (Vc)

TIC: ID [ABM/AT2] Ref [aam1n10:12] Method [ESI+]

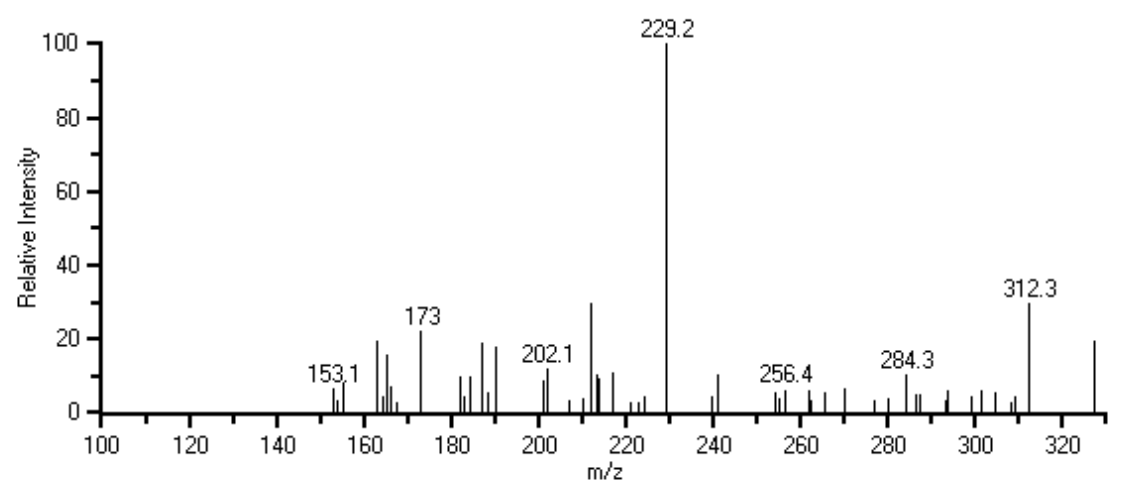

Fig. 5: Mass spectrum for compound (Vc)

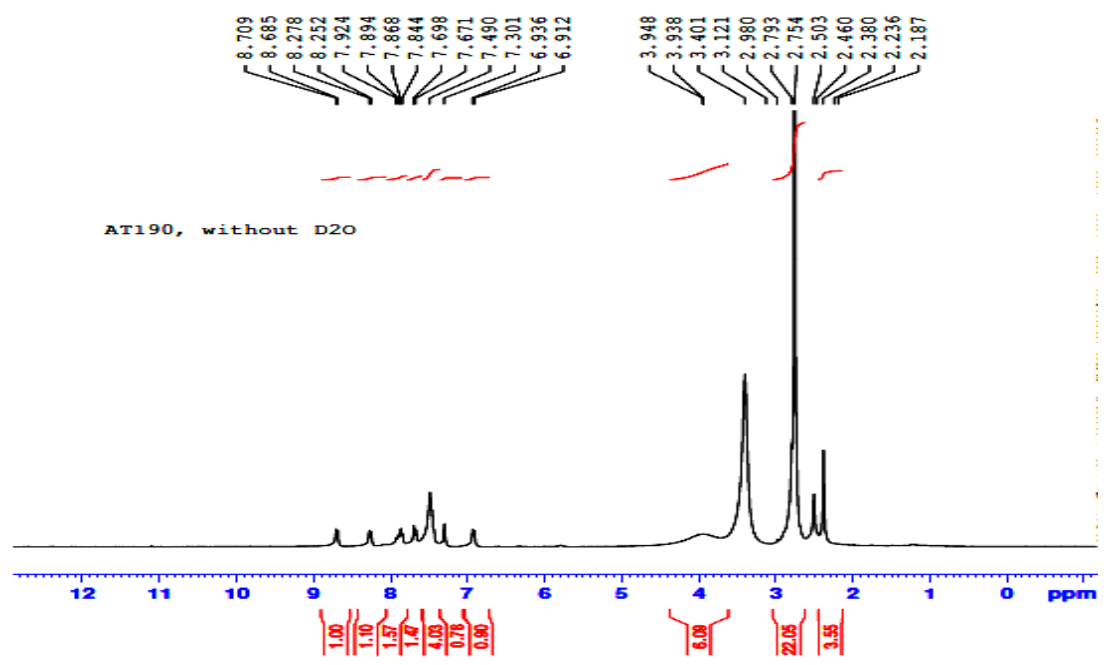

Fig. 6: ${ }^{1} \mathrm{H}-\mathrm{NMR}$ spectrum for compound (VI) 


\section{ACKNOWLEDGEMENTS}

The authors are thankful to the Dean of Science College, University of Mosul and to the Head of Chemistry Department for providing finance for spectral measurements. Also thanks to Dr. M. Almasad, (Al-Bayt University, Jordan) for technical help in NMR measurement. Thanks also to the staff of (I.I.T. Roorkee, India, Chemistry Department) and to (University of Southampton, Chemistry Department) for Mass measurement.

\section{REFERENCES}

Acheson, R.M. (1973). "Chemistry of Heterocyclic Compounds". Volume (9), Chapter (III), "9acridanone". 223p.

Al-Hadedi, O.T. (2009). Synthesis of some $(10 \mathrm{H})$ benzo[b][1,8]naphthyridin-5-one derivatives. M.Sc. Thesis, Mosul University, Coll. of Sci., Dep. of Chem.

Al-Hadedi, A.A. (2008). Synthesis of some new derivatives of benzonaphthyridin. M.Sc. Thesis, Mosul University, Coll. Sci., Dep. of Chem.

Al-Obaydee, S.Z. (2010). Studies on the reaction of some benzonaphthyridine with amine. M.Sc. Thesis, Mosul University, Coll. of Sci., Dep. of Chem.

Atwell, G.J.; Cain Bruce, B.F.; Baguley, C.; Finaly, G.J.; Demny, W.A. (1984). Potential antitumor agents.43. Synthesis and biological activity of dibasic 9-aminoacridino-4-carboxamides, a new class of antitumor agent. J. Med. Chem., 27, 1481-1485.

Bernardino, A.M.; Azerdo, R.A.; Pinheiro, L.C.; Borges, J.C.; Paixao, I.C.P.; Mesquita, M.; Souza. T.M.; Santos, M.S. (2012). Synthesis and anti-HSV-1 evaluation of new $3 \mathrm{H}-$ benzo[b]pyrazolo[3,4-h]-1,6-naphthyridines and 3H-pyrido[2,3-b]pyrazolo[3,4-h]-1,6naphthyridine. Org. Med. Chem. Lett, 23, 1-7.

Bhambi, D.; Salvi, V.K.; Bapna, A.; Pemwat, G.; Talesara, GL. (2009). Synthesis and antimicrobial evaluation of some alkoxyphthalimide derivatives of naphthyridine. Ind. J. Chem., 48B, 697704.

Chandra, T.; Garm, N.; Lata, S.; Saxena, K.K.; Kumar, A. (2010). Synthesis of substituted acridinyl pyrazoline derivatives and their evaluation for anti-inflammatory activity. Euro. J. Med. Chem., 45, 1772-1776.

Chen, Q.; Deady, L.W. (1993). Synthesis of some benzo[b][1,6] naphthyridines and benzo[b][1,7]naphthyridines. Aust. J. Chem., 46, 987-993.

Chen, Q.; Deady, L.W.; Baguley, B.C.; Denny, W.A. (1994). Electron-deficient DNA-intercalating agents as antitumor drugs: azoanalogues of the experimental clinical agent, N-[2(Dimethylamino)ethyl]acridine-4-carboxamide. J. Med. Chem., 37, 593-597.

Chilin, A.; Manzini, P.; Confente, A.; Pastorini, G.; Guiotto, A. (2002). Synthesis of some benzo [c] $[2,6]$ naphthyridine-5-ones and new tetracyclic benzofuro [4,5-c]-2,6-naphthyridin-5(6H)ones. Tetrahedron, 58, 9959-9964.

Deady, L.W.; Rodesam, T.; Zhuang, L.; Baguley, B.C.; Denny, W.A. (2003). Synthesis and cytotoxic activity of carboxamide derivatives of benzo[b][1,6]naphthyridines. J. Med. Chem, 46, 1049-1054.

Deyanov, A.B.; Konshin, M.E. (2004). Synthesis of derivatives of 8-cyano-6-ethoxycarbonyl-3hydroxy-5-methyl-imizazo [1,2-a] pyridine and 9-alkoxycarbonyl-(or 9-carboxy(-3-ethoxycarboxy-2-methyl-10H-benzo [b]-1,8-naphthyridine-5-one from the reaction of 2-chloro-5ethoxycarbonyl-6-methylnicotino nitrile with amino acid. Chem. Heter. Compnd, 40(4), 510513.

Duan, L.P.; Wen, A.D.; Wu, N.B.; Tao, Y.; Zhang, H.B. (2011). Synthesis and anti-intestinal nematode activity of variously substituted benzonaphthydrine derivatives. Molecules, 16, 1593-1602.

Flockerzi, D.; Hummel, R.P.; Reutter, F. (2012). Benzonaphthyridines. US pat 8,198, $295 \mathrm{~B} 2$. 
Gorlitzer, K.; Bode, M.; Jones, PG.; Jomaa, H.; Wiesner, J. (2007). Benzo[c][2,7]naphthyridine-5yl-amine and benzo[h][1,6] naphthy-ridine-5-yl-amines potential antimalarials. Pharmazie, 62, 15-26.

Ivanov, A.S.; Tugushera, N.Z.; Granik, V.G. (2005). Benzo[b]naphthyridines. Russ. Chem. Rev., 74, 915-936.

Jameel, R.K.; Al-Hadedi, A.A. (2010). Synthesis and cyclization of some N-(2-pyridyl) anthranilic acids. J. Raf. Sci., 21(4), 19-29.

Kannappan, N.; Reddy, B.S.R.; Sen, S.; Nagarajan, R.; Dashute, S. (2009). Synthesis and chemical characterization of quinoline Imine derivatives. J. Appl. Chem. Res., 9, 59-68.

Manoj, M.; Prasad, K.T.R. (2011). Synthesis of linear dibenzo [1,8] naphthyridines using 2-chloro4-methyl quinolines. Arkivoc., 289-307, (ix).

Marco, J.L.; Rios, C.; Garcia, A.G.; Villarroya, M.; Carreiras, M.C.; Martins, C.; Eleuterio, A.; Morreale, A.; Orozco, M.; Luque, F.L. (2004). Synthesis, biological evaluation and molecular modelling of diversely functionalized heterocyclic derivatives as inhibitors of acetylcholinesterase/ butyrylcholinesterase and modulators of $\mathrm{Ca} 2+$ channels and nicotinic receptors. Bioorg. Med. Chem., 12, 2199.

Meftah, H.; Brouant, P.; Charbit, J.J.; Placidi, M.; Galy, A.M.; Galy, J.P., Oyfer, J.C.; Barbe, J.; Mesavalle, C.; Castill, C.J.J.; Osuma, A.; Richarson, M.; Sharples; D. (1994). Synthesis, trypanocidal activity and DNA bending of new benzo[b][1,8]-naphthyridonesderivatives. Heter. Commun., 1(1), 27-35.

Ming, L.; Zhou, Z.M.; Wen, L.R.; Qiu, Z. (2011). Chemistry of heterocyclic ketene aminals: construction of imidazo (pyrido)[1,2- $\alpha]$ pyridines and imidazo(pyrido)[3,2,1-ij][1,8]naphthyridines via DABCO-catalyzed tandem annulations. J .Org. Chem., 76, 3054-3063.

Pincheiro, L.C.S.; Borges, J.C.; Oliveira, C.D.; Ferreira, V.F.; Romeiro, G.A.; Marques, P.I.; Abreu, P.A.; Frugulheti, I.C.P.P.; Rodrigues, C.R.; Albuquerqul, M.G.; Castro, H.C.; Bernardino, A.M.R. (2008). Synthesis of new 4-(phenylamino)thieno[2,3-b]pyridines and derivatives of the novel benzo[b]thieno[3,2-h]-1,6-naphthyridine tetracyclic system. Arkivoc., (xiv), 77-87.

Tabart, M.; Picaut, G.; Desconclois, J.F.; Malen, D.S.; Huet, Y.; Berthaud, N. (2001). Synthesis and biological evalulation of benzonaphthyridones, a series of new topical antibacterial agents. Bioor. Med. Chem. Lett., 11, 919-921.

Tabart, M.; Picaut, G.; Levergne, M.; Wentzler, S.; Multeron, J.L.; Malen, D.S.; Berthand, N. (2003). Benzo[f]naphthyridone: A new family of topical antibacterial agents active on multiresistant gram-positive pathogens. Bioorg. Med. Chem. Lett, 13, 1329-1331.

Tian, C.; Jiao, X.; Liu, X.; Li, R.; Dong, L.; Liu, X.; Zhang, Z.; Xu, J.; Xu, M.; Xie, P. (2012). First total synthesis and determination of the absolute configuration of 1-N-methyl-3-methylamino[N-butanoic acid -3-(9-methyl-8-propen-7-one)-amide]-benzo[f][1,7] naphthyridine-2-one, a novel benzonaphthyridine alkaloid. Tet. Lett., 53, 4892-4895.

Yi, Y.; Feng, Z.Y.; Ying, Z.J.; Yue, W. (2008). Synthesis and luminescent properties of a Schiff base-boron-quinacridone compounds. Chin. Sci. Bull., 53(11), 1651-1656. 